\title{
Effect of rainfall and temperature on liver and rumen fluke infestations of bovines in Sri Lanka
}

\author{
L.D. AMARASINGHE ${ }^{*}$ and H. L. N. N. KUMARA \\ Department of Zoology, University of Kelaniya, Sri Lanka. \\ * Corresponding author, Tel: +94(0)11 2903398,E-mail: deepika@kln.ac.lk
}

\begin{abstract}
Fecal fluke egg output of bovines from three selected farms at Ma Eliya (site A), Ma Eliya (site B) and Delathure (site C) in Ja-Ela area of Gampaha district in Sri Lanka was examined for six months period from July to December 2006. The mean egg output of the animals of site A, B and C were 255, 84 and 95 eggs/g of feces respectively. Statistical analysis showed that mean fecal fluke egg output was significantly different between sites $(\mathrm{df}=2, \mathrm{f}=126.05, \mathrm{p}=0.000)$ and also between months $(\mathrm{df}=5, \mathrm{f}=7.31, \mathrm{p}=0.000)$. Regression analysis revealed that the fecal fluke egg output had a positive relation with rainfall $\left(\mathrm{r}^{2}=0.6178\right)$ and a negative relation with temperature $\left(r^{2}=0.6486\right)$. The female cattle had a higher fecal fluke egg output $(x=202.76)$ than the male cattle $(\mathrm{x}=116.97)$ but egg output did not significantly differ. Also there was an increasing trend of mean fecal fluke egg count with the increment in the age of cattle $\left(r^{2}=0.6057\right)$. Rumens and livers of slaughtered cattle and buffaloes from the study area were examined for fluke infections. Specimens were identified by making histological sections. One species of liver fluke, Explanatum explanatum and four rumen flukes, Paramphistomum spp., Gastrothylax crumenifer, Carmyerius spp., and Fischoederius elongates were identified. Two other flukes belonging to the family Gastrothylacidae were also found from the rumen of buffalo. Explanatum explanatum was found to be a great cause of condemnation of livers at slaughterhouses in Sri Lanka.
\end{abstract}

(C) 2007 International Formulae Group. All rights reserved.

Keywords: liver and rumen flukes, bovines, influence of climate, Sri Lanka.

\section{INTRODUCTION}

Cattle (Bos indicus/Bos tarsus) and buffaloes (Bubalus bubalis migona) play a vital role in the agricultural economy of Sri Lanka from ancient times. They are particularly used in land preparation and postharvest processing, while the milk is usually consumed in the form of curd and other byproducts. Cattle farming contributes to about $20 \%$ of the milk and milk products in Sri Lanka (Thilakarathne, 1974) while beef contributes as an important source of animal protein. They also provide manure that is widely used by local farmers as a cheap source of fertilizer.

Diseases caused by liver flukes and gastrointestinal or stomach flukes result in major economic losses in cattle, buffaloes and goats. It is estimated that more than 300 million bovines are exposed to these parasites worldwide (FAO, 1994). As in other countries in the tropics, fluke infection is the greatest single constraint to livestock in Sri Lanka (Faizal, 1995). Senadhira (1967) had listed the trematode parasites recorded in agricultural animals in Sri Lanka. According to this author, five genera of digeneans, namely, Gastrothylax, Paramphistomum, Calicophoron, Ceylanocotyle and Fischoederius are reported to occur in gastrointestinal tract while two genera namely, Fasciola and Explanatum occur in the liver of the cattle. However, information on fecal egg out put of bovines in relation to climatic conditions in this country is scanty but that will be a useful tool for timing the treatments against fluke infection. 
The objectives of the present study were: to find out the egg output of liver and rumen flukes of cattle and buffaloes in Ja-Ela area of Gampaha district in Sri Lanka; to determine whether the rainfall and the temperature have any effect on flukes egg production; and to take a post-mortem survey on flukes that were found in rumen and condemned livers of cattle and buffaloes in JaEla area.

\section{MATERIALS AND METHODS}

\section{Egg output of rumen and liver flukes}

Three cattle/buffaloes farms from three small villages each at Maeliya south (site A), Maeliya north (site B) and Delathure (site C) were selected from Ja-Ela area of the Gampaha district in Sri Lanka (Figure 1). Each herd at Site A, B and C consisted of seven cattle, eight buffaloes and five cattle each with the sex ratio of $4: 3,3: 5$ and $4: 1$ (male:female) respectively. The age of the animals varied between 2.5 and 4 years. All the animals reared at site $\mathrm{B}$ and $\mathrm{C}$ were found healthy while only two female individuals of the age of four and three years reared at site A were found lean. Animals in all the three farms were allowed to graze in open abandoned fields.

About $50 \mathrm{~g}$ of fresh fecal samples (dung) from individual animals $(n=20)$ of the three selected farms were collected into thick polythene bags separately. $5 \%$ formalin that is enough to soak the dung was added to each polythene bag to prevent the further development and hatching of eggs. The bags were labeled and were brought to the laboratory. Thirty grams of feces were weighed and mixed in $150 \mathrm{ml}$ of $0.1 \mathrm{~N} \mathrm{NaOH}$. This mixture was strained through a $0.5 \mathrm{~mm}$ mesh. A suspension of $0.15 \mathrm{ml}$ was taken from the middle of the suspension using a $1 \mathrm{ml}$ pipette and it was transferred onto a clean glass slide and covered with a coverslip. The slide was observed under light microscope at X40 magnification and the total number of liver and rumen fluke eggs under the entire coverslip was counted $(\mathrm{N})$.

$$
\text { No. of eggs } / \mathrm{lg} \text { of dung }=(\mathrm{N} / 0.15) \mathrm{X}
$$$$
(150 / 30)=\text { N X } 33
$$

Fluke egg output from individual animals from the three farms was counted at monthly interval from July 2006 to December 2006 and the mean fecal fluke egg output was determined.

Daily Rainfall and temperature data were obtained from the nearest data collection center at Regional Agriculture Research and Development Center at Makandura, Gonawila, Sri Lanka.

\section{Isolation and killing of liver and rumen flukes}

Samples of suspected liver and rumen portions from seven slaughtered cattle and buffaloes lived in the study area were immediately submitted to the laboratory in sealed polythene bags for the detection of flukes and fluke lesions. Samples were placed in trays separately. Bile ducts of liver samples were opened using a pair of scissors and all flukes adhering to it were detached with a pair

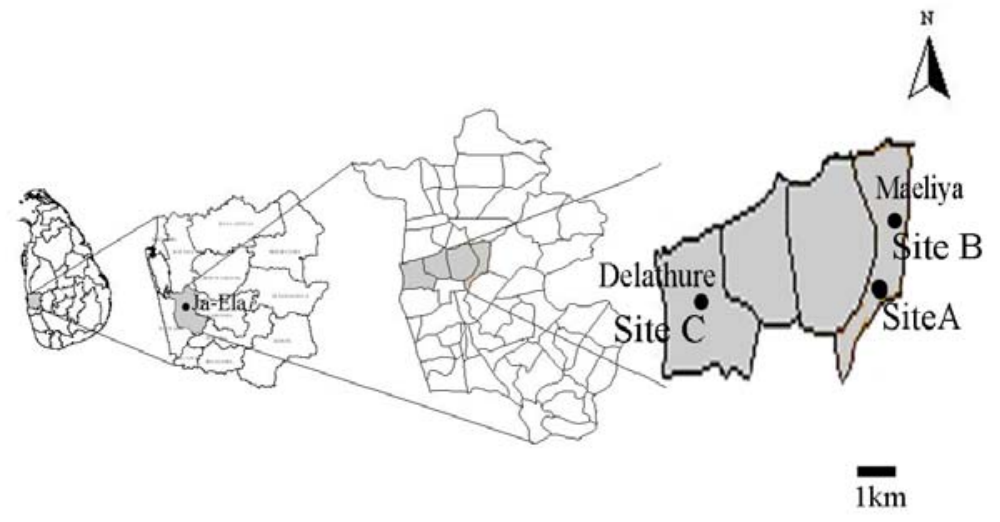

Figure 1: Location of the study sites A, B, and C. 
of forceps. Amphistomes inhabited in the rumen were easily detached with a pair of forceps. Flukes collected from liver and rumen of individual carcasses were collected into separate containers. They were thoroughly washed with saline to remove blood and mucus; allowed to relax in distilled water to extend and expel eggs. They were then killed by putting them into $10 \%$ formal saline (5 to 10 minutes) and washed with mammalian saline twice to remove formalin.

\section{Preparation of stained histological sections of liver and rumen flukes:}

Alcohol formalin/acetic acid fixative was heated to $60{ }^{\circ} \mathrm{C}$ and washed flukes were fixed for 24 hours. Then they were stored in $10 \%$ buffered formalin until further processing. Fixed specimens were embedded in wax blocks. About $14 \mu \mathrm{m}$ thick sagittal sections of the specimens were obtained using the microtome and they were laid on labeled glass slides. Sections were given two changes of xylene, each longing two minutes. Then they were given two changes of absolute alcohol, each longing two minutes. Then the specimens were washed in running tap water. After that the specimens were stained with Haematoxyline for 35 minutes and differentiated in acid alcohol. They were again washed in running tap water and were stained with Eosin for 5-10 minutes. They were then washed in running tap water and were given two rapid changes in absolute alcohol. Specimens were cleared in xylene and mounted in DPX mounting medium.

Specimens were identified using their appearance and location within the host. The main identification features included, the colour, shape and size of the specimen, presence or absence of an oral sucker and a ventral pouch, arrangement of intestinal caeca, and location and appearance of testes and ovary etc. This was enabled by the keys published by International Institute of Parasitology (1996).

\section{Statistical analysis}

Statistical software package MINITAB $^{\circledR}$ release 14 , C $1972-2004$ Minitab Inc was used for data analysis. Mean fecal egg counts were analyzed using one-way ANOVA to examine whether the egg counts are significantly different between test animals, sites (farms) and months. The accepted level of significance was $\mathrm{P} \leq 0.05$. Tukey's pair wise comparison was done to examine what sites are significantly different in mean fecal fluke egg count from each other. Regression analysis was done to examine whether mean fecal egg count has any correlation with monthly mean rainfall and monthly mean temperature during the study.

\section{RESULTS}

\section{Egg output of rumen and liver flukes}

The mean egg output over six months period of wet weather from July - December 2006, for all the animals in site A, B and C were 255 (range 72.6-330), 84 (range 13.2112.2) and 95 (range 19.8-171.6) eggs/g of feces respectively. One-way ANOVA revealed that there was a significant difference in egg output among the study sites $(\mathrm{df}=2, \mathrm{f}=$ 126.05, $\mathrm{p}=0.000$ ), between the test animals $(\mathrm{df}=8, \mathrm{f}=57.03, \mathrm{p}=0.000)$ and months $(\mathrm{df}=5$, $\mathrm{f}=7.31, \mathrm{p}=0.000$ ).

Female cattle had a higher mean fecal fluke egg output $(x=202.76)$ than the male cattle $(x=116.97)$ but did not significantly differ $(\mathrm{df}=1, \mathrm{f}=1.83, \mathrm{p}=0.248)$. In cattle there was an increasing trend of mean fecal fluke egg count with increment of age (Figure 2).

The highest rainfall and the lowest temperature were recorded in the month of October. In the month of November, the highest egg output was recorded from the test animals (Figure 3a\&b). Regression analysis revealed that there was a positive relation between mean egg count/g and monthly mean rainfall over the study period $\left(r^{2}=0.6178\right)$ (Figure 4a) while there is a negative relation between mean egg count/g and monthly mean temperature $\left(r^{2}=0.6486\right)$ (Figure $\left.4 b\right)$.

\section{Adults of rumen and liver flukes}

During this study, five liver and rumen flukes were identified belonging to two subfamilies of Suborder- Prosostomata of Order- Digenea of Class- Trematoda of Phylum- Platyhelminthes and are shown in Table 1. Two unidentified flukes were collected from the rumen of buffaloes and they belonged to the Family Gastrothylacidae (Plates 1 and 2). Rumen fluke infection is always found in mixed infection. 
Table 1: Recorded liver and rumen flukes during the study.

\begin{tabular}{|c|c|c|}
\hline Fluke & $\begin{array}{l}\text { Location } \\
\text { in the host }\end{array}$ & Appearance and main identification features \\
\hline $\begin{array}{l}\text { Explanatum explanatum } \\
\text { (Creplin, 1847) } \\
\text { Subfamily } \\
\text { Paramphistominae }\end{array}$ & Liver & $\begin{array}{l}\text { Live worms were bright red in color and turned into } \\
\text { whitish color after killing them using } 10 \% \text { formal } \\
\text { saline. } \\
\text { Major identification features: } \\
\text { Body is conical shape, curved ventrally, } 6-10 \mathrm{~mm} \\
\text { in length and } 3-5 \mathrm{~mm} \text { width; acetabulum is sub } \\
\text { terminal and enormous, 3-4mm in external } \\
\text { diameter; no oral sucker; alimentary canal is well } \\
\text { developed; they do not have an esophageal bulb; } \\
\text { intestinal caeca are lateral, wavy, reaching up to } \\
\text { acetabulum and end blindly; vitelline follicles are } \\
\text { in lateral fields extending from level of pharynx to } \\
\text { acetabulum; ventral pouch absent; two tandem } \\
\text { testes are lobed; ovary is post testicular }\end{array}$ \\
\hline $\begin{array}{l}\text { Paramphistomum } \\
\text { (Fischoeder, 1901) } \\
\text { Subfamily } \\
\text { Paramphistominae }\end{array}$ & Rumen & $\begin{array}{l}\text { Live worms were bright red in color and turned into } \\
\text { whitish color after killing them using } 10 \% \text { formal } \\
\text { saline. } \\
\text { Major identification features: } \\
\text { Smaller in size, } 5-9 \mathrm{~mm} \text { in length, } 2-3 \mathrm{~mm} \text { in } \\
\text { width; oral sucker absent; acetabulum is sub } \\
\text { terminal, moderate in size and it is about } 1.5-2.5 \\
\mathrm{~mm} \text { in external diameter; intestinal caeca in lateral } \\
\text { fields form irregular bends throughout their course } \\
\text { reaching up to the acetabulum; Vitelline follicles } \\
\text { are in lateral fields extending from level of pharynx } \\
\text { to acetabulum; ventral pouch absent; two tandem } \\
\text { testes are lobed; ovary is inter-testicular }\end{array}$ \\
\hline $\begin{array}{l}\text { Gastrothylax crumenifer } \\
\text { (Ceplin, 1847) } \\
\text { Subfamily } \\
\text { Gastrothylacinae }\end{array}$ & Rumen & $\begin{array}{l}\text { Live worms were bright red in color and turned into } \\
\text { whitish color after killing them using } 10 \% \text { formal } \\
\text { saline. } \\
\text { Major identification features: } \\
\text { Body is conical shape and curved ventrally; oral } \\
\text { sucker absent; acetabulum is terminal and small in } \\
\text { size, } 1.5-4.5 \mathrm{~mm} \text { in external diameter; alimentary } \\
\text { canal is well developed; intestinal caeca are long, } \\
\text { lateral wavy, reaching up to the anterior level of } \\
\text { testes and end blindly; vitelline follicles are small } \\
\text { and extending from intestinal fork to acetabulum; } \\
\text { ventral pouch present; testes are deeply lobed and } \\
\text { locate side by side between caecal ends and } \\
\text { acetabulum; ovary is inter-testicular }\end{array}$ \\
\hline $\begin{array}{l}\text { Carmyerius sp } \\
\text { (Stiles \& Goldberger, 1910) } \\
\text { Subfamily } \\
\text { Gastrothylacinae }\end{array}$ & Rumen & $\begin{array}{l}\text { Live worms were red in color and turned into } \\
\text { grayish color after killing them using } 10 \% \text { formal } \\
\text { saline. } \\
\text { Major identification features: } \\
\text { Elongated body, } 7-11 \mathrm{~mm} \text { in length and } 2-4 \mathrm{~mm} \\
\text { in width; acetabulum is terminal, small in size, } 1- \\
2 \mathrm{~mm} \text { in external diameter; lack oral sucker; } \\
\text { alimentary canal is well developed; intestinal } \\
\text { caeca are straight, reaching up to posterior region } \\
\text { of body; ventral pouch present; testes are lobed } \\
\text { and locate lateral of the body; ovary is inter- } \\
\text { testicular }\end{array}$ \\
\hline
\end{tabular}




\begin{tabular}{|c|c|c|}
\hline $\begin{array}{l}\text { Fischoederius elongates } \\
\text { (Poirier, 1863) } \\
\text { Subfamily } \\
\text { Gastrothylacinae }\end{array}$ & Rumen & $\begin{array}{l}\text { Live worms were red in color and turned into } \\
\text { grayish color after killing them using } 10 \% \text { formal } \\
\text { saline. } \\
\text { Major identification features: } \\
\text { Smaller and elongated body, } 10-14 \mathrm{~mm} \text { in length } \\
\text { and 3-4 mm in width; oral sucker absent; } \\
\text { acetabulum terminal, small in size, } 2-3 \mathrm{~mm} \text { in } \\
\text { external diameter; alimentary canal is well } \\
\text { developed; intestinal caeca are lateral, wavy, } \\
\text { pass the posterior testis and end blindly; } \\
\text { Vitellaria are small, situated in lateral field } \\
\text { extending from esophageal bifurcation to ovary; } \\
\text { elongated triangular shape ventral pouch present; } \\
\text { lobed, tandem testes; ovary is inter-testicular. }\end{array}$ \\
\hline $\begin{array}{l}\text { Unidentified spp. } 1 \\
\text { Subfamily } \\
\text { Gastrothylacinae }\end{array}$ & Rumen & $\begin{array}{l}\text { Live worms were red in color and turned into } \\
\text { grayish color after killing them using } 10 \% \text { formal } \\
\text { saline. } \\
\text { Major identification features: } \\
\text { Smaller and elongated body, } 5-8 \mathrm{~mm} \text { in length } \\
\text { and 3-4 mm in width; oral sucker absent; } \\
\text { acetabulum terminal and small in size, } 1-2 \mathrm{~mm} \\
\text { diameter; vitellaria extend throughout the body } \\
\text { length; triangular shape ventral pouch present }\end{array}$ \\
\hline $\begin{array}{l}\text { Unidentified spp. } 2 \\
\text { Subfamily } \\
\text { Gastrothylacinae }\end{array}$ & Rumen & $\begin{array}{l}\text { Live worms were red in color and turned into } \\
\text { grayish color after killing them using } 10 \% \text { formal } \\
\text { saline. } \\
\text { Major identification features: } \\
\text { Smaller and elongated body, } 6-8 \mathrm{~mm} \text { in length } \\
\text { and } 2-4 \mathrm{~mm} \text { in width; oral sucker absent; } \\
\text { acetabulum terminal and small in size, } 1.5-2 \mathrm{~mm} \\
\text { diameter; Vitellaria are small, situated in lateral } \\
\text { field extending from esophageal bifurcation to } \\
\text { ovary; ventral pouch present }\end{array}$ \\
\hline
\end{tabular}

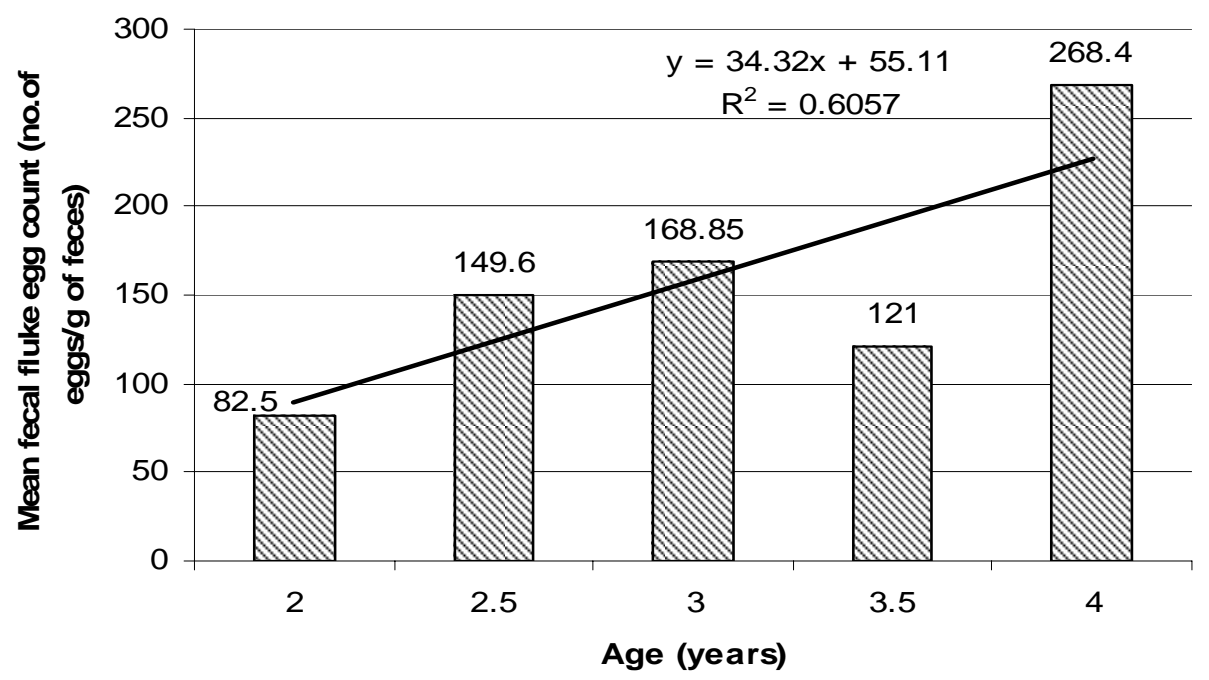

Figure 2: Variation of mean fecal fluke egg output in cattle with the age 
(a)

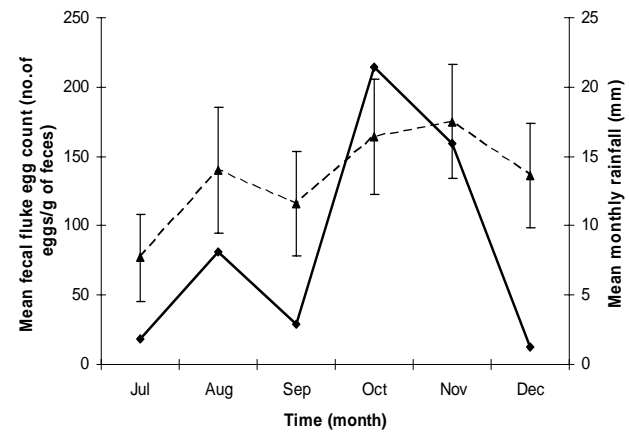

$-\downarrow-$ mean fecal fluke egg count $\longrightarrow$ - mean monthly rainfall (b)

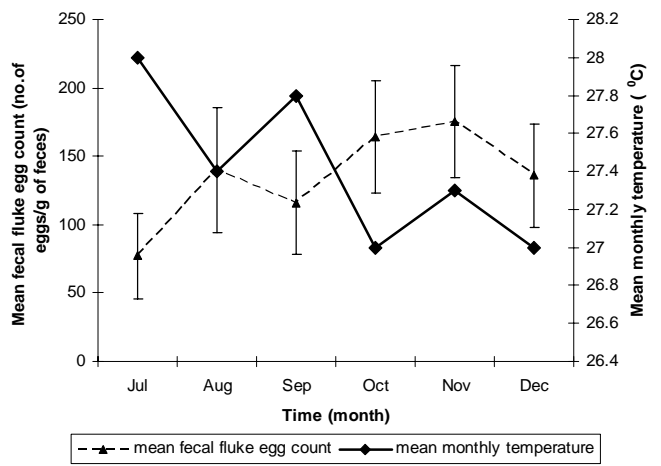

Figure 3 (a \& b): Mean fecal fluke egg output and mean rainfall (a) mean temperature (b) over the time

(a)

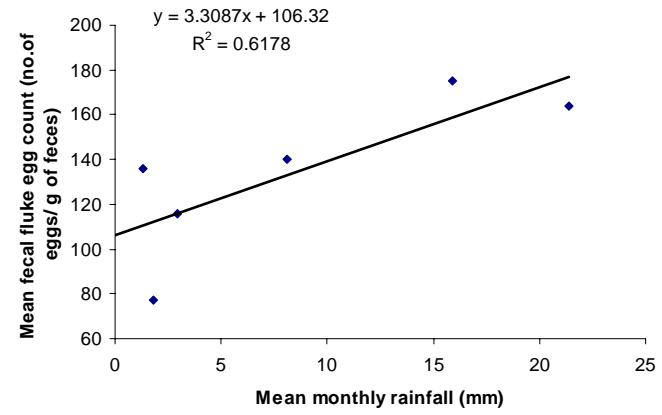

(b)

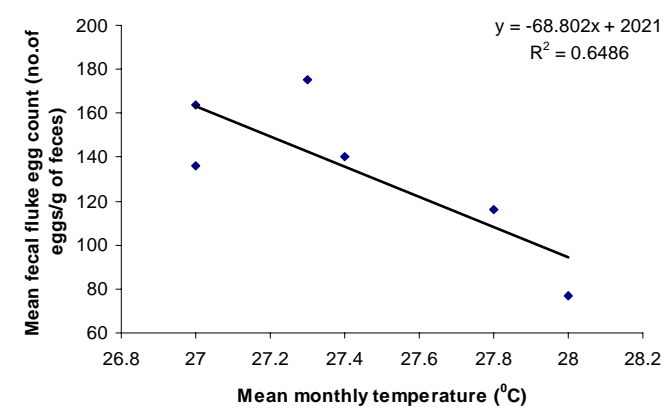

Figure 4 (a \& b): Relationship between mean monthly rainfall (a), mean monthly temperature (b) and mean fecal fluke egg output

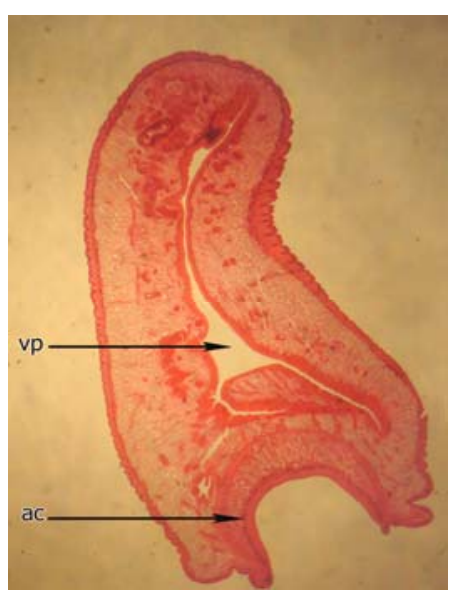

Plate 1: Unidentified fluke species 1. (X 25). ac- acetabulum vp- ventral pouch

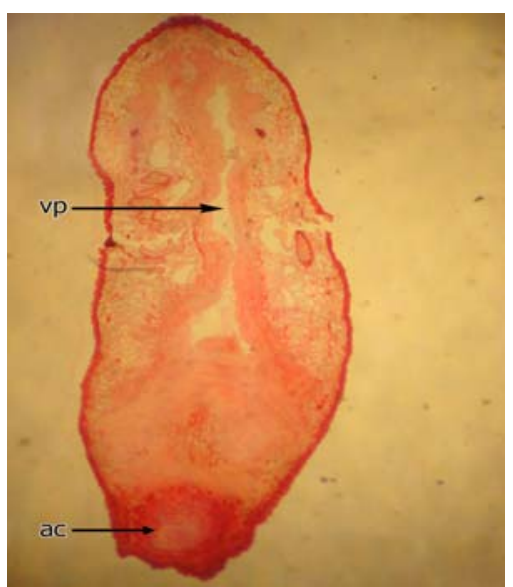

Plate 2: Unidentified fluke species 2. (X 30). ac- acetabulum vp- ventral pouch 


\section{DISCUSSION}

For trematode parasites in cattle, a fecal egg output of 100-200 eggs/g of feces is considered pathogenic. Almost all of the test animals had fecal egg outputs reaching or exceeding this level. Egg output was within the range of 13.2-330 fluke eggs/g of feces. Animals that had the highest fecal egg output were lean and unhealthy in appearance.

The present study revealed that there was a significant different in fecal egg output between study sites. This may be due to variety of factors such as the age and sex of the animals, their grazing facilities and the environmental conditions. The variation of relative abundance of intermediate hosts at each site could have caused the significant difference in mean fecal fluke egg count between sites. Aquatic snails were more abundant in site A than in Site B and C. Sites, $\mathrm{A}$ and $\mathrm{B}$ (situated at Maeliya were more inland and where fresh water ditches, streams and large water bodies were common. However, Site $\mathrm{C}$ at Delathure was situated more towards the sea and is usually flooded with brackish water during high tide. Also, snails are washed off by the large stream in Site B, the main source of drinking water for animals during floods.

The present study also revealed that there was an increasing trend of mean fecal fluke egg output with the increment in the age of the host animal. This may be due to the reason that animals do not develop resistance against fluke infection with the increment of age.

In Sri Lanka, two seasons are recognized, the rainy season and the dry season and the present study was carried out during the rainy season. It was evident from this study that there was an increasing trend of egg output with increasing rainfall. This makes possible to determine a monitoring and control program for flukes. The time for treatments can be determined based on this study towards the tail end of wet weather or before the beginning of dry weather.

Among the rumen flukes, Gastrothylax crumenifer, Fischoederius elongates, Paramphistomum and liver fluke, Explanatum explanatum have been previously reported from cattle in Sri Lanka (Senadhira 1967;
Faizal, 1995). Carmyerius carmyerius was not reported by these authors. However, Carmyerius carmyerius was collected from cattle carcass in Gampaha district in Sri Lanka in 1998 (Darshika, 1998). Two fluke species, Fasciola hepatica and F. indica were reported in condemned liver samples during 1960s (Senadhira, 1967). However, Fasciola hepatica or F. indica did not recover from any of the samples during the study. It is confirmed that these flukes are amphistomes (lacking oral sucker) and the majority of them infect rumen in bovines. However, more serious infection is due to Explanatum explanatum in liver. Infested liver samples were always found seriously damaged by Explanatum explanatum and the parasites were found in large numbers adhering to the bile duct and liver. The presence of Explanatum explanatum is the major cause of condemnation of livers at slaughterhouses in Sri Lanka. Fibrosis caused by these parasites around the bile ducts and the liver can cause loss of body weight. FAO (1994) reports that there is a limited number of chemicals that can be used safely to control an outbreak of fluke infections and some of these chemicals can be used to treat both paramphistomes and adult liver flukes. Therefore, one can select such chemicals for treating the infected bovines based on the fecal fluke egg output. However, further studies during the dry season of the year are necessary for more prophylactic measurements to be taken based on the climatic data, rainfall or temperature.

\section{ACKNOWLEDGEMENTS}

Authors acknowledge Mr. D.D.R. Upali Wanigasekera, Senior Staff Technical Officer of the Department of Zoology of the University of Kelaniya, Sri Lanka, for his valuable assistance in getting section preparation of specimens.

\section{REFERENCES}

Darshika. 1998. A preliminary survey of liver and gastro-intestinal helminth parasites in cattle in Gampaha district. A project report submitted as a partial requirement of the B.Sc.(Special) degree in Zoology of the University of Kelaniya, Sri Lanka, p.67. 
FAO. 1994. Diseases of domestic animals caused by flukes. Epidemiology, diagnosis and control of Fasciola, paramphistome, Dicrocelium, Eurytrema and schistosome infections of ruminants in developing countries. FAO-UN: Rome; p.49.

Faizal ACM. 1995. Helminthiasis in livestock and poultry in Sri Lanka: a review of literature. Sri Lanka Vet. J., 42(2): 1-8.

Gupta NK, Dutta T. 1967. Gastrothylax crumenifer, a common pouched amphistomid parasite of ruminants in India. Res. Bull. Panjab Univ., New series, 18: 369-337.

Hansen J, Perry B. 1994. The epidemiology, diagnosis and control of helminth parasites of ruminants. International Laboratory for Research on Animal Diseases: Nairobi, Kenya; p.171.

International Institute of Parasitology. 1996. Helminthology Manual: International training course on identification of helminth parasites of economic importance. International Institute of Parasitology: St. Albans, Herts, UK.

Thilakarathne N. 1974. Some studies on beef production in Sri Lanka. Ani. Prod. and Health Bull., 8: 59-64.

Senadhira MPA. 1967. The parasites of Ceylon(ii) Trematoda. Cey. Vet. J., 15(2): 33-41. 